\title{
CESPUC
}

\section{GENERATIVE THEORY: PERSPECTIVES AND CHALLENGES}

\author{
Arabie Bezri Hermont* \\ Gláucia do Carmo Xavier**
}

In recent years, we have witnessed an increase in the interest in studies that investigate the relationship between cognition and language. This edition is organized around that perspective, as it presents research papers, which are the result of investigations conducted inside eLinC (Studies in Language and Cognition), a research group from PUC Minas, created with the intention of studying several phenomena, including those of grammatical nature in Brazilian Portuguese, in light of Generative Theory.

The studies here presented demonstrate the search for understanding of phenomena of syntactic-morphological character involved in the grammar of adult individuals and in the acquisition of mother tongue.

Noam Chomsky was the forerunner of this theoretical current and the originator of the large epistemological leap, which took place in the 1950s of the last century. Since then, the tradition of the relationship between Grammar and Cognition has been initiated in language studies. The Generative Theory, by assuming that linguistic knowledge may be better explained taking into consideration the nature of the mind, poses the existence of a universal grammar and innate knowledge, biologically coded. It is also assumed that the mind could be organized in modules and that language faculty is one of those. That, in turn, could also be characterized by modularity, with syntax being one module that composes language faculty.

Another assumption of generative grammar is that it is ruled by the universality criterion, that is, there are general principles that explain the organization of natural languages. Alongside these universal principles, there would be parameters to be chosen, which, for being motivated by morphological differences, are the boosters for the development of studies within this theoretical frame.

An example of this principle is that there is a grammatical subject in every natural language, which may or may not be reproduced phonetically. The language parameters would, therefore, determine the differences. English is a language in which the subject is explicit, whereas in Italian, it is not. Once expressed in discourse, a native Italian speaker knows that it is not necessary to make the subject explicit.

In this sense, the study of parameters is directly connected to functional categories, as they are the triggers of syntax. Lexical words have descriptive content, such as names, verbs and adjectives. Yet, functional categories perform another role as they carry grammatical *Professora do Programa de Pós-graduação em Letras da PUC Minas. Doutora em Linguítica pela UFRJ. Coordenadora do Grupo de Pesquisas eLinc (Estudos em Linguagem e Cognição).

*Professora de dedicação exclusiva do Instituto Federal de Minas Gerais (IFMG), atuando no Ensino Médio e Mestrado ProfEPT. Líder do Grupo de Estudo sobre Ensino e Aprendizagem de Língua Portuguesa e Literatura (GEALI). Doutora em Linguística e Língua Portuguesa (PUC-MG). Coordenadora do projeto da FAPEMIG intitulado "Verbos de ligação: Representação no módulo mental, natureza sintática e relações com o aspecto verbal". 
information. The conjunctions 'que', 'se' and 'para' (in English, 'that', 'if' and 'to', respectively) are examples of words that are parallel to functional categories and are called complementizers, which introduce embedded clauses, as "Ele disse que o Pedro comeu o biscoito" (He said that Peter ate the cracker), "Ele quis saber se você comeu o biscoito" (He wanted to know if you had eaten the cracker) and "Ele disse para você comer o biscoito" (He told you to eat the cracker). Auxiliary verbs and verbal morphemes encode tense, form and aspect, and therefore, are considered components that correspond to functional categories, as in "Lucas está comendo biscoito" (Lucas is eating crackers), in which both the auxiliary 'está' (is) and the ending -ndo (-ing) encode grammatical notions. In the first instance, the notions of form, tense and aspect are expressed, while in the second instance, solely the information regarding the progressive aspect is presented. Determiners encode gender and number, thus, assuming the role of functional category, such as in "O menino deu uns doces a sua irmã" (The boy has given some candies to his sister). The article 'o' is masculine, singular and definite, whereas, the article 'uns' is masculine, plural and indefinite.

Thus, we can deduce from the previous examples that functional categories are a group of traits that are present within the mental grammar. In the following syntax tree, a complementizer component would, for example, occupy the C nucleus from a CP (Complementizer Phrase). A verb would have its final position, in the derivation of a phrase in $\mathrm{T}$ (Tense) and nucleus of a TP (Tense Phrase).

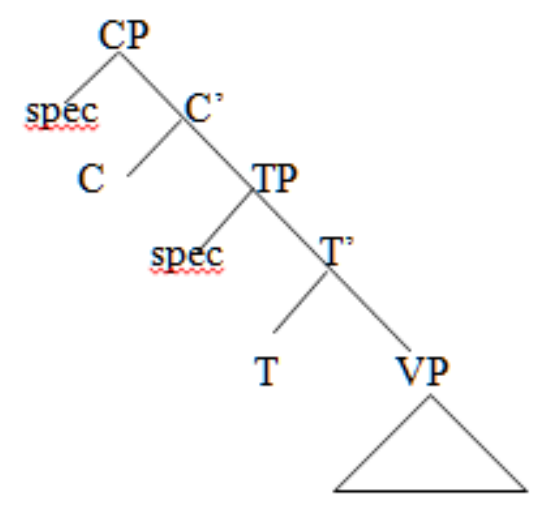

It is interesting to observe that, throughout generative studies, there have been several suggestions of division of the functional categories. Rizzi (1997), as an example, has suggested that the CP projection should be divided in four nodules, which are: strength (named ForceP); topic (named TopP); focus (named FocP), and finity (named FinP). The projection ForceP would have the classical function attributed to a $\mathrm{CP}$, which is to have the role of attributing to the sentence declarative, interrogative, imperative or exclamatory strength. FocP would have, as a nucleus, a component which would be moved to the beginning of the sentence in order to gain focus, as in "Biscoito, eu não comi", in which the object is moved from its position to the beginning of the sentence, in order to be specially emphasized. Analyzing it from a discourse perspective, the focus would be on a new piece of information, that is, a piece of information that would not have been previously mentioned in discourse and presumably would not be familiar to the listener. Between the projection of strength (the highest) and the 


\section{CESPUC \\ 20 SEMESTRE DE 2018 - N. 33}

projection of focus, there would be, according to Rizzi, a layer named Topic. In this projection, differently from the projection of focus, there would be an old piece of information, which would have already been mentioned in discourse and, therefore, would be presumably known to the listener. The fourth functional projection of the $\mathrm{CP}$ would be the FinP, a finitess phrase, which would indicate if a clause is finite or non-finite.

There have already been several proposals of divisions for the flexional layer as well. Since Emonds (1976), this notion of division can be said to exist. The researcher has proposed a binary marking for the inflection node. Then, a finite clause would be marked as [+T, +AGR] and a non-finite clause, [-T, -AGR]. Pollock (1989), has developed Emonds' proposal even further and, through observing the movement of verbs in regards to adverbs, quantifiers and negation particles in the finite and non-finite forms, in English and French, he has proposed that there should be an agreement node (AGR) and a tense node (which, in the occasion, was named as I - from Inflection), as demonstrated in the following syntax tree (IP, in this perspective, would correspond to TP).

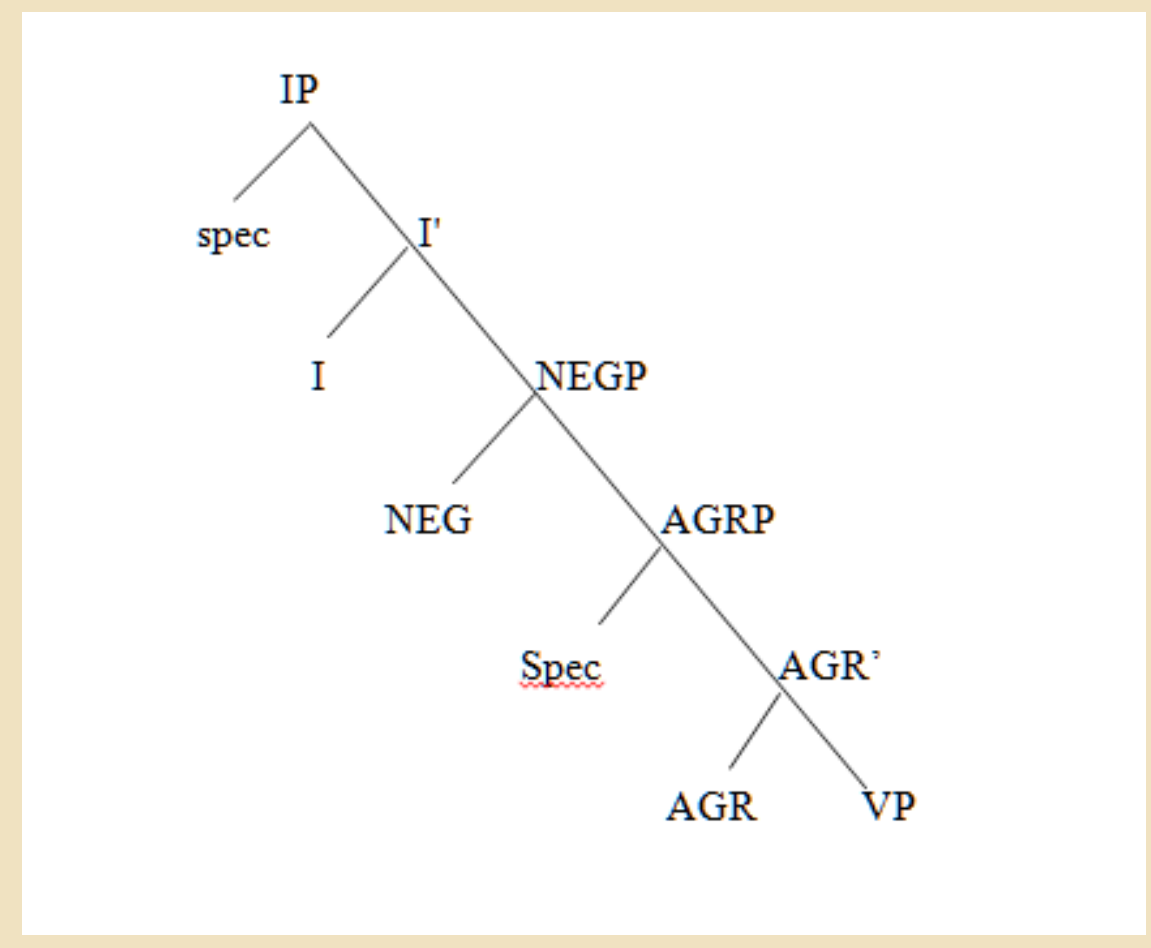

This syntax tree had been adopted for some time until Chomsky (1995), in which AGR stops being a node composing a syntagma, as there would be no semantic interpretability. Thus, the TP (former IP) becomes the place where the verbal inflection takes place. In the perspective of indicating a new division of the projection related to inflection, some studies like (Hermont, 2015), (Hermont \& Morato, 2014), (Xavier, 2016) points us towards the possibility of verbal aspect being a functional category, besides the TP. In order to delve deeper into this subject, in the next section, we turn to the explanation of what tense and verbal aspect are.

Tense would situate the moment of occurrence of a given situation in the past, present or future, and aspect is connected to different forms of verifying the internal temporal constitution of a 


\section{CESPUC \\ 20 SEMESTRE DE 2018 - N. 33}

situation, that being, its duration: if concluded or unconcluded.

There are several ways of approaching the aspectual notion. For the purpose of this presentation, we can mention Comrie (1976, p.25), who classifies the aspectual oppositions in perfective and imperfective. The first notion views situation as a unique whole, without distinction between the many separate phases that comprise that situation. The second notion is connected to a given internal structure of a situation and it is subdivided in habitual and continuous, and the latter subdivided in non-progressive and progressive. The notions of perfectiveness and imperfectiveness are important as the studies developed on eLinC that treat the notions of tense and aspect adopt a syntax tree with an aspectual node where [ $+/$ - perfectiveness] traits are given value, and a temporal node, where $[+/$ - past $]$ traits are given value.

In Hermont (2005) and Hermont \& Morato (2014), for example, it is adopted a syntax tree with a node for temporal inflection and another one for aspectual inflection. It is possible to observe, as an example, that in the following syntax tree, when the verb is part of the derivation of the sentence, there would be, initially, valued traits in the nucleus of the Aspectual Syntagma, and following, in the Temporal Syntagma nucleus.

\section{Temporal and aspectual notions in the syntax tree - Simple verbal form}

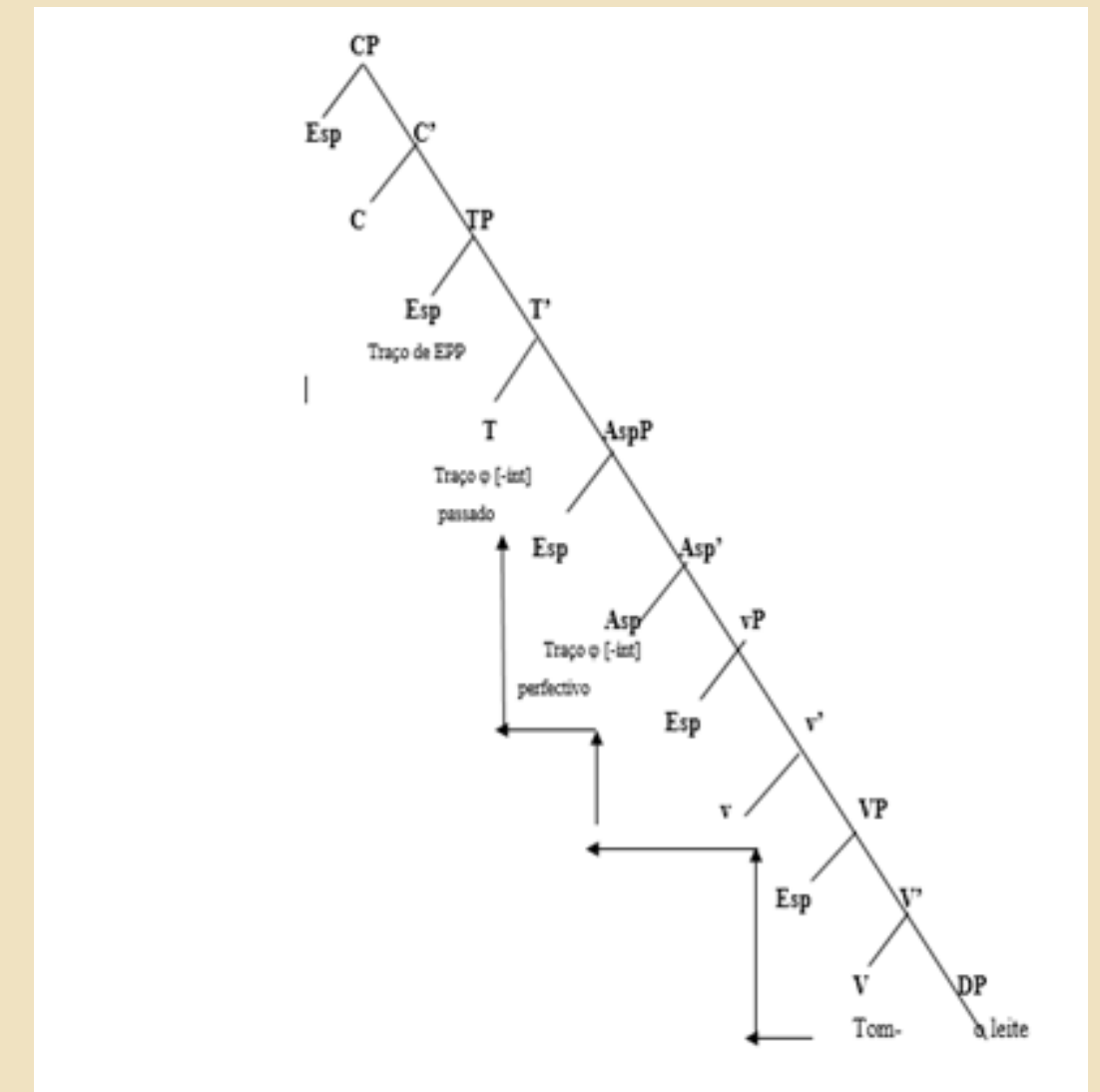

Source: Hermont \& Morato (2014, p.228)

When it comes to verbal periphrasis (auxiliar + main verb), the idea is for the auxiliar to be generated in the Temporal Syntagma nucleus and the main verb have the aspectual traits given value in the Aspectual Syntagma, as it is demonstrated in the syntax tree as follows: 


\section{CESPUC

\section{Temporal and aspectual notion in the syntax tree - Verbal Periphrasis}

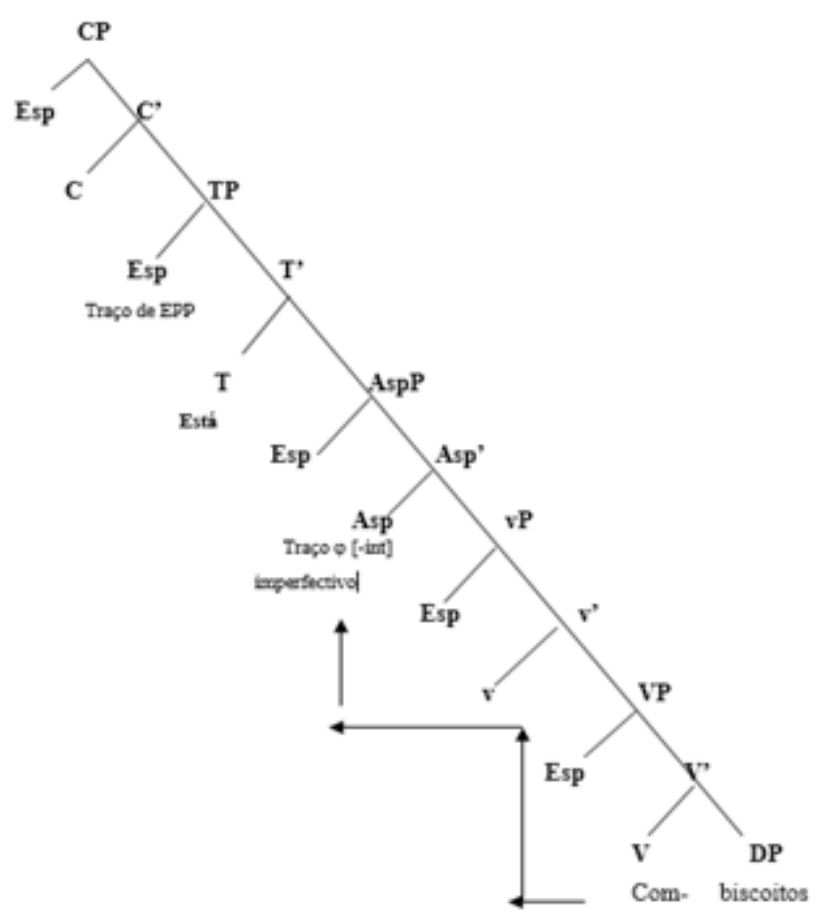

Source: Hermont \& Morato (2014, p. 229)

In recent years, some approaches have determined changes in the studies within the theoretical framework of Generative Theory. One study that has marked this change was Hauser, Chomsky and Fitch (2002), that establishes a distinction between language faculty in the writing aspect (FLN) and language aspect in the broad aspect (FLB). The first would include solely the computational system and mapping for the interfaces, and the second would give relevance to the interface system, thus broadening the studies that have aimed at understanding the relationship between language and cognition. Another change seen in recent studies in Generative Theory is related to the understanding of parameters of the Principles and Parameters Theory, which is strongly connected to the formal traits of the lexicon.

After having presented some assumptions of The Generative Theory, one central concern of the linguistic and of cognitive theories can be posed: how do human beings acquire language? Within generative studies, the consensus is that we are adapted for the task of acquiring language and language development is the consequence of inapt capabilities and shaped by the environment.

Children, as long as they are exposed to the language of their linguistic group, acquire a hierarchically organized system of categories and abstract rules. Thenceforth, children have the ability of producing and understanding sentences which go beyond the restrict set of sentences they have heard throughout the process of language acquisition. Children in typical growth, develop in a short period of time, a rich and highly abstract system of norms that constitutes 
the grammar of their language. In addition, the child seems to be provided with a generative system, that is, a combinatorial system of constituents, lexical and functional, that derive a sentence. In other words, children are capable of producing and understanding sentences that present arguments and verbs in positions which are non-canonical, or that present phonetically void arguments. They are able to produce and understand sentences with anaphora pronouns and attach it to a referent present in discourse, without any mistake.

It is within that spirit that scholars of generative theory dwell on studies about language acquisition, as this faculty of human species seems to have some particular ease for computing highly complex sentences comprised of pronouns and void elements. As an example, a child knows unconsciously that there is a difference between 'O policial perseguia o ladrão' (The police officer chased the thief) and 'O ladrão perseguia o policial' (The thief chased the police officer). That is, the child knows that those have distinct meanings. The child also knows that in 'O policial conhecia o ladrão que não gostava dele' (The police officer knew the thief who did not like him) 'him' refers to 'the police officer'. Finally, consciously, a child knows that, in 'Nós jantamos e $\varnothing$ fomos embora' (We had dinner and left), the subject from 'fomos' is the same one from 'jantamos'.

Therefore, the child who acquires a language seems to acquire an ability for computing that allows them to produce and combine structures according to system's principles and restrictions. Therefore, when a child demonstrates to comprehend a given linguistic expression, they go beyond the chain of surface, that is, of what can be heard sonorously. Children are able to understand, in a sentence, both linguistic elements outside a canonical position and void elements.

Within this context, several studies have been developed in the eLinC group, in light of Generative Theory. The first article of this section is entitled 'Generative Theory: historical context and perspectives' from Gisely Gonçalves de Castro. The theoretical text presents the trajectory of the generative enterprise, since its emergence in the 1950s - Chomsky (1957) - going through the Aspects of the Theory of Syntax (CHOMSKY, 1965), Lectures on Government and Binding (CHOMSKY, 1981), The Minimalist Program (CHOMSKY, 1995), coming to more recent work that demonstrates new alignments from the Generative Theory, such as Hauser, Chomsky and Fitch (2002). Castro promotes a history of the various phases of generativism, since its advent, with its initial approaches, to the Initial Transformational Theory and Standard Theory, in which notions as base synthatic component and transformational component are brought about.

When discussing Aspects of the theory of syntax, from 1965, the author highlights the Deep Structure, which contains every necessary information for the semantic interpretation of sentences. For the model of Theory of Regency and Connection, Castro emphasizes the notions connected to the X-bar Theory and to the trace proposal, which has enabled a new analysis to the transformations that involved movement, and comes to the Minimalist Program, portraying the crucial role of lexicon, interface systems and principles of economy proposed by Chomsky (1995). In the end, Castro shows notions that are present in Hauser, Chomsky \& Fitch (2002), demonstrating the role of syntax recursion, as the recent development in the Homo sapiens 
evolution and highlighting the importance of the theoretical framework by trying to explain how complex language is.

The next four articles discuss language acquisition in light of generative theory. The first one is Morato \& Ziegler, who have developed a study on tense and aspect, comparing data from Brazilian Portuguese and Mexican Spanish. The authors demonstrate, through data of language acquisition in both languages, that there are productions with morphemes or verbal forms only connected to aspect, as well as productions with notions of both tense and aspect. If there are linguistic productions with only one of the notions, it is clearly dissociated on mental grammar. Based on Wexler (1998), the authors propose that, in the grammar of children in language acquisition phase, there must be a restriction, in which aspect and tense traits are not always given value. The authors have also aimed at investigating, in both languages, the relationship between lexical/semantic aspect and grammatical aspect. In other words, predicates marked by the telicity trait tend to come up in the perfective form, as those marked by atelicity would be more common in imperfective verbal forms. In data from both native-speaker children from Brazilian Portuguese and Mexican Spanish, the authors have verified that close relationship, confirming results that had already been reached in several studies in different languages.

The text by Ana Lúcia Barros Leôncio, entitled 'The null object in language acquisition', is justified by the following: if the possibility of having a null object in a language is a parameter, this is a relevant theme in the agenda of studies regarding language acquisition. That happens because, if there is variation and change, the child will fix a relative parameter to the object (explicit or null). Leôncio, based on different authors who deal with the theme, conducts her research with children from zero to 5 years and 9 months. For the author, the phonetically null objects must be favored, in Brazilian Portuguese, in contexts in which the antecedent is undefined/non-specific or inanimate. Thus, after selecting every sentence produced by children participating in the study, Leôncio verified whether there was a phonetically explicit object or null object, observing if such component had its antecedent characterized by traits of animation and specificity. The data obtained in the conducted study indicate that null object antecedents are preferably marked by the [-animate] and [+specific] traits.

If for the former two articles, a concern regarding the understanding of the nature of language and how children acquire it and put it to use is present, the article by Kelcius Rodrigues Ferreira, named 'The acquisition of language by children with Williams syndrome: a case study about the comprehension of passive sentences', brings something interesting to the generative studies. The text presents the result of a case study and it is aimed at verifying the comprehension ability of passive sentences by a ten-year-old child with Williams Syndrome. This is a rare disease, genetically determined, that reveals itself through a cognitive, behavioral and communicative deficit. The author presents the Hypothesis of Prolonged Deficit in A-Chains Formation (EACDH), proposed by Perovic and Wexler (2010) and, through the conducting of tests such as sentence-picture correspondence, common to language acquisition studies from the perspective of Generative Theory, it has been verified that a child with Williams Syndrome performed poorly in understanding long passive sentences, in comparison to the control group, composed by children in typical linguistic development. The results 
found by Ferreira reinforce the postulation of Perovic and Wexler (2010) and the arguments in favor of the modularity of language.

Amanda Carvalho Souza, in the article entitled 'The production of monoargumental verbs in the process of language acquisition' justifies the reason why if it is understood that individuals are biologically programmed to acquire any language, it is relevant a study that aims to verify if children in the process of grammar development are able to produce sentences with argument movement. The author, based on Palmiere (2002) and Ciríaco \& Cançado (2004), presents results of a research with the production of moargumental verbs, namely: unergative and unaccusative verbs. The unergatives canonically appear in the SV order, and have in the subject position, a syntagma with the thematic role of agent. On the other hand, unaccusative verbs may appear in the SV or VS order, and present, in the subject position, a syntagma with thematic role of patient. The author aimed at verifying in which phase the unergative and unaccusative structures appear, and in which order the verbs occur, whether in SV or VS order. Another objective was to observe the relationship between the type of monoargumental verb and the semantic aspect, as it is usual in literature, to find unergative verbs characterizes by atelicity, and the unaccusative, by telicity. The results of the research developed by Souza reveal that unergative verbs occur exclusively in the order subject-verb, and the unaccusatives appear, preferably, in that order. That is interesting as it allows us to verify that a child, at young age, is able to apply the synthatic operation of movement, as the only argument of unaccusative verbs is generated in the object position of a sentence. Also as a result of the study conducted, it is possible to verify that, in children's speech the unaccusative and unergative verbs have occurred more times in atelic predicates, which has not confirmed what was previously predicted in the study, as it was expected that unaccusative verbs would have a greater occurrence in telic predicates. One of the possible reasons for that second result might have been the inclusion of linking verbs in the unaccusative group.

Gláucia do Carmo Xavier, Eduardo Kenedy and Kelly de Oliveira motivated by a very similar result to Souza's in a previously developed study (Xavier (2016)), now present an article entitled 'Formal study of linking verbs: synthatic nature and representation in the mental module'. The authors have conducted their research by answering the following questions: How can a formal representation of sentences with linking verbs be made? Do copula verbs, elevational verbs and linking verbs have the same grammatical status? Can the linking verb be understood as an unaccusative verb? For such, a bibliographic study has been conducted initially in the attempt of differentiating linking verbs from elevational verbs, copular verbs and unaccusative verbs. After that, a group of defining traits from linking verbs have been established and prototyping tests of unaccusativity have been used in the research. It could be verified that linking verbs have common traits to copular, elevational and unaccusative verbs, however, the intersection that is built, is not enough to declare that linking verbs are synonyms to any other kind of verb. In the study in question, it is stated that linking verbs do not select an external argument, but instead select a small clause syntagma, as an internal argument. In addition, this kind of verb does not impose semantic restriction to the structural subject, and does not accept the subject's postposition in a natural way, as it often occurs with unaccusative verbs. It is proposed, in this article, that sentences with linking verbs encompass a syntagma 


\section{CESPUC \\ $2^{\circ}$ SEMESTRE DE $2018-$ N. 33}

for a small clause in detriment to the existing VP and any other functional syntagma for the linking verbs.

From this panoramic presentation of six texts that compose this collection, we take on the challenge of extending to the reader an invitation to reflect on the performing of studies that favor the search for understanding of linguistic phenomena and processes of language acquisition, from the point of view of Generative Theory.

\section{REFERENCES}

CHOMSKY, A. N. Aspects of the Theory of Syntax. Cambridge: The MIT Press, 1965.

CHOMSKY, A. N. Lectures on Government and Binding. Dordrecht: Foris Publications, 1988 [1981].

CHOMSKY, N. Syntactic Structures. The Hague: Mouton, 1985 [1957].

CHOMSKY, N. The Minimalist Program. Cambridge: Massachusetts. The MIT Press, 1995.

CIRÍACO, Larissa; CANÇADO, Márcia. Inacusatividade e inergatividade no PB. Cadernos de Estudos Linguísticos, Campinas, v.46, n.2, p. 207-225, jul/dez. 2004.

COMRIE, Bernard. Aspect. Cambridge: Cambridge University Press, 1976.

EMONDS, Joseph. A transformation approach to syntax. New York: Academic Press, 1976.

HAUSER, M. D.; CHOMSKY, N.; FITCH, W. T. The Faculty of Language: What is it, Who has it, and How did it Evolve? Science, New York, v. 298, p. 1569-1579, nov. 2002.

HERMONT, Arabie Bezri. Tempo e Aspecto no DEL. 2005. 273f. Tese (Doutorado em Linguística) - Programa de Pós-Graduação em Linguística, Universidade Federal do Rio de Janeiro, Rio de Janeiro, 2005.

HERMONT, Arabie Bezri; MORATO, Rodrigo Altair. Aquisição de tempo e aspecto em condições normais e no déficit específico de linguagem. Revista LinguíStica / Revista do Programa de Pós-Graduação em Linguística da Universidade Federal do Rio de Janeiro. Volume 10, número 1, junho de 2014. ISSN 1808-835X 1. [http://www.letras.ufrj.br/poslinguistica/ revistalinguistica]

PALMIERE, Denise Telles Leme. A inacusatividade na aquisição da linguagem. 2002. 198f. Tese (Doutorado em Linguística) - Instituto de Estudos em Linguagem, Universidade Estadual de Campinas, Campinas, 2002.

PEROVIC, A.; WEXLER, K. Development of verbal passive in Williams syndrome. Journal of Speech, Language and Hearing Research, v. 53(5), p. 1294-1306, 2010.

POLLOCK, Jean-Yves. Verb movement, universal grammar, and the structure of IP. Linguistic 


\section{CESPUC}

Inquiry, v. 20, n. 3, p. 365-425, 1989.

RIZZI, Luigi. The fine strucuture of the left periphery. In: HAEGEMAN, L. Elements of grammar. Dordrecht: Kluwer, 1997.

WEXLER, Kenneth Very early parameter setting and the unique cheking constraint: a new explanation of the optional infinitive stage. Lingua, v. 106, p. 23-79, 1998.

XAVIER, Gláucia do Carmo. O estudo do aspecto em uma perspectiva minimalista: representação sintática e relações com categorias funcionais e lexicais. 2016. 236f. Tese (Doutorado em Linguística e Língua Portuguesa) - Programa de Pós Graduação em Letras, Pontifícia Universidade Católica de Minas Gerais, Belo Horizonte, 2016. 